\title{
ACID VIOLENCE: A BURNING ISSUE IN BANGLADESH
}

\author{
Gulshan Ara Akhter ${ }^{1}$ and Farzana Islam ${ }^{2}$
}

Department of Forensic Medicine, Ibrahim Medical College, 122 Kazi Nazrul Islam Avenue, Dhaka

\begin{abstract}
Acid violence is a barbaric form of violence in Bangladesh. Acid violence also called acid throwing or vitriolage, is defined as the act of throwing of strong corrosives on face and body of a person with the intention of causing permanent disfiguration, intense pain, scarring and sometimes blindness. All of these injuries are considered as 'grievous hurt' under section 320 of B.P.C (Bangladesh Penal Code). For the last few years it is on the rise in both urban and rural areas of Bangladesh. The perpetrators are mostly men and adolescent boys. The overwhelming majority of the victims are women and many of them are girls and young females. Recently, however, there have been acid attacks on children, older women and also men. These attacks are often the result of family and land dispute, dowry demands or a desire for revenge due to failure in love affairs or marriage proposals. It is considered as one of the extreme forms of repression and violation of women's right. This review article is aimed to focus on the present situation of this barbaric act of vengeance against women and young adolescent girls with regard to frequency, causes, long term consequences and creating public awareness on the issue by tightly regulating the sale and transport of acid as well as enacting harsher penalties for perpetrators.

Data collection is based on information from Dhaka Medical College hospital, One Stop Crisis Center (OCC), Acid Survivors' Foundation, Naripokkho Action Aid and several Dhaka based organizations.

Ibrahim Med. Coll. J. 2013; 7(1): 18-20
\end{abstract}

Key words: Acid violence, Grievous hurt, Women rights violation.

\section{Introduction}

Acid violence is one of the worst manifestation of violence against women. Acid attacks occur throughout South East Asia, especially in Pakistan, India, Cambodia and Bangladesh. Globally at least 1500 persons in 20 countries were attacked last year in this way, $80 \%$ of whom being females and somewhere between $40 \%$ and $70 \%$ under 18yrs of age. In Bangladesh, acid throwing are mostly a form of domestic violence primarily targeted at women. It is a relatively recent form of violence. The first documented case of acid attack occurred in 1983 in Sylhet. ${ }^{1}$ In Bangladesh, there have been many incidence of acid attacks due to dowry disputes leading often to blindness, disfigurement and death. In 2002, 315 women and girls in Bangladesh were victims of vitriolage.
The chemical agents most commonly used to commit these attacks are sulphuric acid, hydrochloric acid and nitric acid. These acids have a catastrophic effect on human flesh, causing the skin tissue to melt, often exposing the bones below the flesh, sometimes even dissolving the bones. Acid is cheap and easily available and is the quickest way to destroy a woman's life. ${ }^{2}$

\section{Incidences of Acid Violence}

The number of acid attacks have been rising in Bangladesh. Documentation from ASF reveals that young women are commonly the targets of acid attacks. Out of total 252 women assaulted with acid, from 1995 to $1998,134(53 \%)$ were below 20 years of age,

Address for Correspondence:

Dr. Gulshan Ara Akhter, Associate Professor, Department of Forensic Medicine, Ibrahim Medical College, 122 Kazi Nazrul Islam Avenue, Dhaka 1000 
Table 1: Frequency of Acid attacks from 1990-2001

\begin{tabular}{l|l|l|l|l|l|l|l|l|l|l|l}
\hline 1990 & 1991 & 1992 & 1993 & 1994 & 1995 & 1996 & 1997 & 1998 & 1999 & 2000 & 2001 \\
\hline
\end{tabular}

\begin{tabular}{llllllllllll}
\hline 21 & 20 & 29 & 39 & 19 & 51 & 83 & 117 & 120 & 117 & 174 & 252
\end{tabular}

Source: National dailies (Prothom Alo, Bhorer Kagoj, Shomokal, Amar Desh)

$8(3 \%)$ were minor girls below 10 years of age. During January-March 1993, 33 persons were victims of acid attacks of which 23 were female and 10 were male.

Tables 1 and 2 show the scenario of Acid attacks on women over the years. These cases are only the reported cases and may not reflect the real situation of the violence against women.

\section{Causes and Consequences of Acid Violence}

1. Lack of self-defence: Women are not socialized to protect themselves and despite an active feminist movement in the country, they are not physically trained to protect themselves.

2. Male ego and problems in dealing with rejection is another important cause of acid throwing. Refusal of love, marriage proposals and family disputes are three major causes of this type of violence. After marriage when dowry demands are not met, brides may become victims of acid throwing.

Other causes of acid throwing include family dispute, protest of husband's second marriage, failure to misappropriate wife's wealth, sterility and getting divorce from wife, refusal of sexual relationship, failure to kidnap, the woman not being agreeable to prostitution and the woman's refusal to agree with husband's second marriage. ${ }^{3}$

Table 2: Cases of reported acid throwing against women by years

\begin{tabular}{ll}
\hline 2002 & 214 \\
2003 & 207 \\
2004 & 191 \\
2005 & 183 \\
2006 & 145 \\
2007 & 147 \\
\hline
\end{tabular}

Source : National dailies (Prothom Alo, Amar Desh, Noya Digonto, Dainik Aparadh Kantha)
Table 3: Incidence of Acid assaults followed up with the police

\begin{tabular}{l|c|c|c|c}
\hline Year & $\begin{array}{c}\text { Total } \\
\text { no. of } \\
\text { incidents }\end{array}$ & $\begin{array}{c}\text { Age } \\
\text { range } \\
2-17\end{array}$ & $\begin{array}{c}\text { Age range } \\
\text { Above } \\
18 y r s\end{array}$ & $\begin{array}{c}\text { No.of } \\
\text { people } \\
\text { assaulted }\end{array}$ \\
\hline Nov 1998-Dec 1999 & 123 & 56 & 88 & 144 \\
2000 & 131 & 57 & 122 & 179 \\
2001 & 171 & 77 & 169 & 246 \\
Jan-July 2002 & 159 & 86 & 151 & 237 \\
Total & 584 & 276 & 530 & 806 \\
\hline
\end{tabular}

Source: Naripokkho, monitoring state interventions to combat violence against women

The illegal sale of acids, cheap and easy availability in any roadside shop is considered an important factor contributing to the practice of acid violence. Impunity, protection of criminals by the politically powerful, and the information about the possibility of assaulting others with acid are probably the main reasons behind the increase in incidences of acid assaults. ${ }^{4}$ Lack of proper infrastructure and transport facilities is a factor that makes acid violence all the more harmful.

\section{Place of acid violence}

Many cases of acid violence occur within the woman's own home and at night. In rural areas or even in urban slums, houses are mainly made of bamboo and thus they can easily be broken into. Such insecurity in the place of residence makes women more vulnerable to attacks by men in their area. ${ }^{5}$ In many cases the acid is aimed at women's genitalia. This is achieved because shared toilets are located at a distance from their houses. Either they are attacked in toilets or acid is placed in the water they use to clean themselves with.

\section{Legislation}

The "Nari O Shishu Domon Act 2000" is intended to address the need for more effective prosecution of

Table 4: Age category of victims of acid attack: VAW, 2008

\begin{tabular}{c|c|c|c}
\hline $\begin{array}{l}\text { Girls } \\
\mathbf{1 0 - 1 8}\end{array}$ & $\begin{array}{c}\text { Women } \\
\mathbf{1 9 - 4 9}\end{array}$ & $\begin{array}{c}\text { Women } \\
\mathbf{5 0} \& \text { above }\end{array}$ & $\begin{array}{c}\text { Total } \\
\text { victims }\end{array}$ \\
\hline 1 & 60 & 0 & 61 \\
\hline
\end{tabular}

Source: Multi-sectoral programme on Violence against Women(VAW), Ministry of Women and Children Affairs, 2008 
Table 5: Causes of Acid Attack (1995-98)

\begin{tabular}{lccccc}
\hline Causes & 1995 & $\mathbf{1 9 9 6}$ & $\mathbf{1 9 9 7}$ & $\mathbf{1 9 9 8}$ & Total \\
\hline Refusal in love & 4 & 15 & 23 & 2 & 44 \\
Refused marriage proposal & 9 & 9 & 13 & 2 & 33 \\
Family dispute & 6 & 8 & 11 & 8 & 33 \\
Dowry & 2 & 1 & 10 & 2 & 15 \\
Refusal to agree to husband's & 1 & - & 2 & 1 & 4 \\
$\quad$ second marriage & & & & & \\
Refusal to sexual relationship & 1 & 3 & 12 & - & 16 \\
Failure to kidnap & 1 & 2 & 3 & - & 6 \\
Acid attack by husband & 5 & - & - & - & 5 \\
Others & - & - & - & 8 & 8 \\
Unknown & 9 & 13 & 13 & 10 & 88 \\
Total & 38 & 51 & 51 & 33 & 252 \\
\hline
\end{tabular}

Source: Compiled from data of Ain-o-Shalish Kendra Documentation Unit

perpetrators. In 2002, Bangladesh introduced the death penalty for throwing acid and laws strictly controlling the sale, use, storage and international trade of acids. The two major laws relating to acid violence are The Acid Crime Prevention act 2002 and The Acid Control Act $2002 .^{6}$

\section{Rehabilitation of the acid victims}

A survivor of acid violence often requires medical attention during the crisis period. In addition, she also often needs protection, safe accommodation, support, counseling and legal assistance. Victims with acid burn demonstrate a wide range of emotional responses including anger, frustration, irritability and psychological states such as delirium, anxiety, depression and grief. Post traumatic stress disorder (PTSD) may occur after an acid burn. ${ }^{7}$ These patients need help from primary or specialized care providers like "Acid Survivors Foundation" to recover psychologically. Consequently the victim is faced with physical challenges which requires long term surgical treatment as well as psychological challenges, which require in-depth intervention from psychologists and counselors at each stage of their physical recovery. Family members should be encouraged to sit with the patient and communicate with them providing a sense of purpose which will help to alleviate feelings of helplessness.

\section{Prevention of Acid violence}

Acid violence can be prevented by passing of strict laws by the parliament, rapid verdict and implementation or punishment by special tribunals, implementation of the dowry prohibition act, regulating the sale of acid, raising awareness in the community, encouraging participation of men against acid violence to women and children, sensitive media reporting, counseling the perpetrator with special focus on adolescent boys. More importantly advocacy, campaign and dialogue with communities particularly with men are essential for bringing forth positive changes.

\section{Conclusion}

The consequence of acid attacks on survivors brings dramatic change in their life style. Most of them have to give up their education or work. Social isolation, fear of further attacks and insecurity damage their self-esteem and confidence. Illiteracy, poverty, threats to further retribution and ignorance about legal support increase their miseries. Gradual increase of acid attacks suggests that legal provisions and its enforcement is not adequate and effective. Data on acid violence must be gathered to monitor changes in this respect. The goals to be achieved by the government is to increase social awareness, psychological support and rehabilitation of the victims and strict enforcement of laws.

\section{References}

1. Swanson, Jordan. "Acid attacks: Bangladesh's efforts to stop the violence". Harvard Health Policy Review 2002; 3: 122-128.

2. Kunkel DB. Burning issues: acids and alkalis,11. Skin and eye exposures: Emerg Med 1984; 16: 165-71.

3. Vij Krishan. Corrosive poisons in Text book of Forensic Medicine and Toxicology: Principles and practice, $5^{\text {th }}$ edition $2011 ; 454-458$.

4. GR Nagesh.Corrosive poisons in Text book of Forensic Medicine \& Toxicology. $2^{\text {nd }}$ edition 2010; 450-452.

5. Mason JK, Purdue BN. Chemical Burns in The Pathology of Trauma. $3^{\text {rd }}$ edition 2000; 345-360.

6. Acid survivors Foundation Bulletin of Bangladesh 2000.

7. Saukko P, Knight B. Corrosive acids, alkalis and phenols in Knight's Forensic Pathology. $3^{\text {rd }}$ edition 2004; 610-619. 